\title{
ANTIEPILEPTIC DRUGS CAUSE LETHAL, SUBLETHAL, TERATOGENIC EFFECTS AND MORPHOMETRIC PARAMETERS ON EMBRYOS AND LARVAE OF ZEBRAFISH (DANIO RERIO)
}

\author{
MEDICAMENTOS ANTIEPILÉPTICOS CAUSAM EFEITOS LETAIS, SUBLETAIS, \\ TERATOGÊNICOS E PARÂMETROS MORFOMÉTRICOS EM EMBRIÕES E LARVAS \\ DE ZEBRAFISH (DANIO RERIO)
}

\author{
Islane Cristina Martins ${ }^{1}$ \\ Pabyton Gonçalves Cadena ${ }^{2}$
}

\begin{abstract}
In the present study, we evaluated the toxic effects of antiepileptic drugs gabapentin (GAB), phenobarbital (PB), oxcarbazepine (OX), and lamotrigine (LTG) the lethal, sublethal, teratogenic effects, and morphometric parameters on embryos and larvae of zebrafish (Danio rerio). An acute toxicity test was performed using D. rerio embryos according to OECD 236 (2013) guidelines. The acute toxicity test revealed that the mortality of animals increased among the time ( 24 to $96 \mathrm{hpf}$ ) on animals exposed to GAB, PB, OX, and LTG. The sublethal effects had a significant $(\mathrm{p}<0.05)$ variation in the number of heartbeats, not a dose-dependent manner. It was also possible to observe variation in the pigmentation in 11 animals and the presence of pericardial edema in some groups. The teratogenic effects revealed the malformation of the head only in the animals exposed to GAB. In addition, tail deformation, spine deformation, yolk sac edema, and inflated swim bladder were observed in all animals. The morphometric parameters had a decrease ( $\mathrm{p}<0.05)$ in body length, head-width, ocular distance, the distance between eyes, and eye diameter in all groups in the $96 \mathrm{hpf}$. It has been observed that gabapentin, phenobarbital, oxcarbazepine, and lamotrigine induce lethal, sublethal, teratogenic effects, and morphometric alterations on zebrafish.
\end{abstract}

Keywords: Gabapentin, Phenobarbital, Oxcarbazepine, Lamotrigine, Toxicity.

RESUMO: No presente estudo, avaliamos os efeitos tóxicos das drogas antiepilépticas gabapentina (GAB), fenobarbital (PB), oxcarbazepina (OX) e lamotrigina (LTG), os efeitos letais, subletais, teratogênicos e parâmetros morfométricos em embriões e larvas de peixe-zebra (Danio ri). Um teste de toxicidade aguda foi realizado usando embriões de D. rerio de acordo com as diretrizes OECD 236 (2013). O teste de toxicidade aguda revelou que a mortalidade de animais aumentou com o passar do tempo (24 a $96 \mathrm{hpf}$ ) em animais expostos a GAB, PB, OX e LTG. Os efeitos subletais tiveram uma variação significativa $(\mathrm{p}<0,05)$ no número de batimentos cardíacos, não de forma dependente da dose. Também foi possível observar variação na pigmentação em todos os animais e a presença de edema pericárdico em alguns grupos. Os efeitos teratogênicos revelaram malformação da cabeça

\footnotetext{
I Biomédica pela Universidade Federal de Pernambuco-PE, mestre em Neurociências pelo Programa de PósGraduação em Neuropsiquiatria e Ciências do Comportamento -UFPE e doutoranda pelo PPGBAS LIKAUFPE. Professional and Self Coach -IBC.E-mail: islanemartins@gmail.com.

2 Doutor em Ciências Biológicas. Pós-Doutorado na IUPUI (Indiana University Purdue University Indianapolis), Estados Unidos. Laboratório de Ecofisiologia e Comportamento Animal (LECA), Universidade Federal Rural de Pernambuco.
} 
apenas nos animais expostos ao GAB. Além disso, deformação da cauda, deformação da coluna, edema do saco vitelino e bexiga natatória inflada foram observados em todos os animais. Os parâmetros morfométricos tiveram uma diminuição $(\mathrm{p}<0,05)$ no comprimento corporal, largura da cabeça, distância ocular, distância entre os olhos e diâmetro do olho em todos os grupos no 96 hpf. Foi observado que gabapentina, fenobarbital, oxcarbazepina e lamotrigina induzem efeitos letais, subletais, teratogênicos e alterações morfométricas no peixe-zebra.

Palavras-chave: Gabapentina, Fenobarbital, Oxcarbazepina, Lamotrigina, Toxicidade.

\section{INTRODUCTION}

Antiepileptic drugs are among the most common teratogenic drugs prescribed to women of childbearing age (Shihmanab, et al., 2019; Li et al., 2020). Approximately I million women of childbearing age have epilepsy, being important to highlight that the continued use of antiepileptic drugs is recommended to reduce the maternal and fetal trauma associated with seizures in the USA (Patel and Pennell, 2016; Kim et al., 2019; Cho et al., 2020). However, prenatal exposure to antiepileptic drugs can cause growth retardation, major congenital malformations, and intelligence deficits in the developing fetus (Kim et al., 2019; Patel and Pennell, 2016; Bhakta et al., 2015). The estimated prevalence of major congenital malformations, such as facial clefts, hypospadias, cardiac defects, and neural tube defects, in the children of epileptic women, is $4^{-10} \%$, which represents a two- to fourfold increase compared to the general population (Bhakta et al., 2015). In Brazil, drugs with central nervous system performance were responsible for $59.9 \%$ of the occurrences according to Toxicology Information Center in women of childbearing age, especially antiepileptics (21.2\%) (Takahama et al., 2014). Gabapentin (GAB), Phenobarbital (PB), Oxcarbazepine (OX), and Lamotrigine (LTG) has been widely used in the treatment of epilepsy, but to the best of our knowledge, few studies on the ecotoxicity of GAB, PB, OX, and LTG can be found in the literature. One way to remedy this need would be to understand the mechanisms of interference of these drugs on evidence-based aquatic organisms. However, understanding these mechanisms encounters problems as evaluating the changes induced by the drugs GAB, PB, OX, and LTG at developmental levels.

Tons of medicines components (i.e., drugs and excipients) including antiepileptics are produced annually worldwide to be consumed by humans or animals. Knowledge of environmental contamination by those compounds grew (Shi et al., 2019). Thus, compelling the scientific community to consider this contamination type as a potential issue meriting concern. The drugs were designed to target specifically to resist inactivation. However, these same properties are responsible either for bioaccumulation and toxic effects in aquatic and terrestrial ecosystems (Santos 
et al., 2010). GAB is eliminated from the systemic circulation by renal excretion (FDA, 20II), and intestinal excretion (Prasad, 2019) as unchanged drug and is not appreciably metabolized in humans (FDA, 20II), a quarter of the administered dose of $\mathrm{PB}$ is excreted unchanged in the urine in neonates and adults (Pacifici, 2014), and intestinal excretion (Yumiko et al., 2019), 2\% of OX is excreted unchanged by the body, as well as carbamazepine and intestinal excretion (Bahlmann et al., 2014). Renal excretion of unchanged LA accounts for less than 10\% (Dickins and Chen, 2002). In addition, the conventional effluents treatment process was found to be invalid for its removal (Martinez et al., 20II; Doll and Frimmel 2005). In Minnesota, researchers sampled 24 sewage treatment plants effluents, and many kinds of drugs were detected, among which the concentration of GAB varied in the $\mathrm{ng} / \mathrm{L}$ range (Writer et al., 2013). The low removal efficiency in these effluents leads to its frequent detection in surface waters worldwide. In the UK and America, GAB has been detected at the concentration level of $\mu \mathrm{g} / \mathrm{L}$ and ng/L (Petrie et al., 2015; Deo, 2014). In Vidy Bay, Switzerland, $\mathrm{GAB}$ has been even detected at a concentration of $400 \mathrm{ng} / \mathrm{L}$ in raw drinking water (Morasch, 2010). The frequent occurrence of $\mathrm{GAB}$ in aquatic systems raises concerns about its ecotoxicity. Besides, studies were not found with the environmental concentrations of PB, OX, and LTG. As already reported above, the toxic effects of these antiepileptics on aquatic biota are not known and, therefore, further studies must be carried out to reveal this knowledge.

Regarding animal model to study ecotoxicological effects like as zebrafish (Danio rerio), a very limited number of articles describes the effect of GAB, PB, OX, and LTG. Therefore, ecological relevance can be underestimated due to the joint effects are different from the predicted sum of individual effects leading to the necessity to develop equivalent concentration and equitoxic ratio tests (Wang et al., 2017). The zebrafish has emerged as an important model for toxicology studies since it is an animal that is susceptible to intoxication by toxic agents. For some types of antiepileptic drugs, the extensive evolutionary conservation of the sequences of their protein targets means that even unicellular eukaryotes can be employed for drug screening and mechanism-ofaction studies (Cunliffe et al., 2015). Network mechanisms in higher non-mammalian systems, such as zebrafish that generate seizures are likely to be similar to those that underlie seizures in mammals. Many other non-mammalian organisms exhibit phenotypes with seizure-like characteristics when the balance between excitatory and inhibitory neurotransmission within the CNS is perturbed (Cunliffe et al., 2015).

Therefore, the aim of the present study was to analyze whether antiepileptic drugs cause lethal, sublethal, teratogenic effects and morphometric parameters on embryos and larvae of zebrafish (Danio rerio). 
Revista Ibero- Americana de Humanidades, Ciências e Educação- REASE

open 2 access 


\section{Material and methods}

\subsection{Chemicals and Reagents}

Gabapentin (GAB), Phenobarbital (PB), Oxcarbazepine (OX), and Lamotrigine (LTG) was purchased from a commercial supplier. All other reagents utilized were of analytical grade.

\subsection{Preparation of stock solutions}

GA in capsules were broken down, and their contents were also diluted in dimethyl sulfoxide $1 \%$ of DMSO solution with a nominal concentration of GAB was $3.0 \times 10^{6} \mu \mathrm{g} / \mathrm{L}$. PB, OX, and LTG drugs were macerated with $\mathrm{I} \mathrm{mL}$ of the $1 \%$ DMSO solution and then diluted in roo $\mathrm{mL}$ of distilled water. The nominal concentration was $1.0 \times 10^{6} \mu \mathrm{g} / \mathrm{L}$ of $\mathrm{PB}, 3.0 \times 10^{6} \mu \mathrm{g} / \mathrm{L}$ of OX, $2.5 \times 10^{5} \mu \mathrm{g} / \mathrm{L}$ of LTG. Then, the solutions were centrifuged with $1512 \mathrm{~g}$ for 15 minutes. Stock solutions of GAB, PB OX, LTG were prepared by the dissolution of supernatants in the distilled water to obtain the

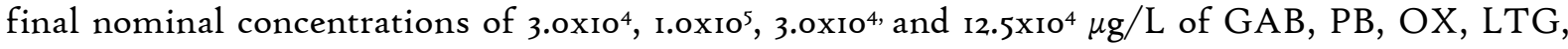
respectively. The solutions prepared were stored under refrigeration $\left(4^{\circ} \mathrm{C}\right)$ for further use. These solutions were renewed daily (Lammer et al., 2009; Yang et al., 2016; Silva et al., 2019; Johannes et al., 2019).

\subsection{Fish maintenance}

The protocols used in this study were approved by the Ethics Committee in the use of animals of the same University, protocol number $112 / 2018$. The experiments were carried out in the Laboratório de Ecofisiologia e Comportamento Animal - LECA, Universidade Federal Rural de Pernambuco - UFRPE. The adult animals used were obtained from a commercial supplier and put in confinement to detect and corroborate the absence of pathogens or diseases. Adult animals were housed for Is days, kept in the aquariums (8o L) in dechlorinated water with artificial aeration (II mg/L DO), the temperature of $26 \pm \mathrm{I}{ }^{\circ} \mathrm{C}, \mathrm{pH} 7.5 \pm 0.5$ with a density of one animal per liter. Nitrite, ammonia, and nitrate were also continuously monitored. The animals were fed twice a day with extruded marketable fish feed (40\% crude protein). All experiments were conducted under a constant artificial dark/light cycle of 1o/14 h (OECD 236, 2013).

\subsection{Egg production}

The day before a test, males, and females in a ratio of 2:1 is placed in breeding chambers immediately before the onset of darkness. The eggs were collected, rinsed in water, and transferred 
to Petry dishes and for determination of the overall egg number and viability (i.e. fertilized) (Silva et al., 2019; Lammer et al., 2009).

\subsection{Selection of eggs}

Eggs were collected and assessed for fertilization success, where the spawning groups with the highest number of fertilized eggs (> 90\%) were selected for testing (OCDE 236, 2013). To identify fertilized eggs, a microscope ( $\mathrm{BIO}_{2} \mathrm{~B}$ SSI with an LED bulb) was used. Eggs with overt anomalies (asymmetries, the formation of vesicles) or damaged membranes were discarded (Lammer et al., 2009; Johannes et al., 2019). For the toxicity test, only fertilized eggs with I hpf (hour postfertilization) were used.

\subsection{Modified fish embryo acute toxicity test (OECD 236)}

The assay was based on the OECD 2036 guidelines for the Fish Embryo Acute Toxicity (FET) Test (OECD, 2013). All groups were exposed to the antiepileptics at I hpf. Animals were divided into groups where each concentration was tested in triplicate (Io embryos per replicate). The study with antiepileptic drugs used a control group and four experimental groups with animals exposed to gabapentin, phenobarbital, oxcarbazepine, and lamotrigine. The control group was exposed to DMSO I\%, a safe concentration for the use of the DMSO as solvent (Zhu et al., 2012) in the toxicity tests. Also, for each compound described above, the experiments were conducted increasing concentrations of each antiepileptic at nominal concentrations of 10, Ioo, and $1000 \mu \mathrm{g} / \mathrm{L}$. These concentrations were based on the environmental concentration of GAB of o.I to ro $\mu \mathrm{g} / \mathrm{L}$ ( $\mathrm{Li}$ et al., 2018) and the environmental concentration of LTG of I to Io $\mu \mathrm{g} / \mathrm{L}$ (Chefetz et al., 2019). However, the environmental concentrations for $\mathrm{PH}$ and $\mathrm{OX}$ were not found and we consider the same concentrations of GAB and LTG for the experiments. Finally, the increasing concentrations (Ioo and rooo times greater than the environmental concentration) for each compound were used to simulating possible concentrations to be found in future years or a large amount of disposal in the environment. During all experiments, water renewal was performed daily with the replacement of antiepileptic concentrations according to OECD 236 (OECD, 2013) guidelines. The endpoints evaluated were lethal, sublethal, teratogenicity, and morphometric parameters.

\subsection{Analysis of the embryonic development}

The analysis of the embryonic development was checked under an optical microscope $\mathrm{BIO}_{2} \mathrm{~B}$ SSI with an LED bulb. The lethal endpoints analyzed were coagulation $(\mathrm{Cg})$, tail not 
detached (Tnd), no somite formation (Nsf), no heartbeat (Nhb), lack of hatching (Lh), and mortality (Mo) (\%) (adaptation from Lammer et al., 2009). The dead animals were removed every day (OECD, 2013). The sublethal developmental endpoints analyzed were the formation of somites (Fs), development of eyes (De), heartbeat/blood circulation ( $\mathrm{Hbc}$ ), heartbeat frequency (Hf), increased pigmentation (Ip), pericardial edema ( $\mathrm{Pe})$, Number of heartbeats $(\mathrm{Nh})(\mathrm{bpm} / \mathrm{min})$ (adaptation from Lammer et al., 2009). The heart rate of the embryos was measured manually by counting the number of heartbeats under an optical microscope (400x, Iooox) (adaptation from Lammer et al., 2009; Yang et al., 2016). Lastly, the endpoints of teratogenicity were malformation of the head (Mhd), malformation of the heart (Mh), tail deformation ( $\mathrm{Td}$ ), spine deformation ( $\mathrm{Sd}$ ), yolk sac edema (Yse), inflated swim bladder (Isb), growth retardation ( $\mathrm{Gr}$ ) and coagulation points (Cp) (adaptation from Lammer et al., 2009). The photographic records of the embryos aided the identification of possible toxic effects during development at 24, 48, 72, and $96 \mathrm{hpf}$. The score determination used in this article is a modification of the data presenting method proposed by Lammer et al. (2009) and OECD 236 (2013). The endpoints collected by dichotomous (binary) response (presence or absence) was based on the severity as well as the number of animals out of the total in which changes were observed with plus $(+)=$ effects until $25 \%$ of animals $(\mathrm{mild}) ;(++)=$ effects in more $25 \%$ until 50\% of animals (moderate); $(+++)=$ more 50\% until $75 \%$ of animals (severe); (++++) more $75 \%$ of animals (very severe).

\subsection{Morphometric parameters}

The morphometric parameters were used to evaluate de toxicity of antiepileptics. Digital images were made of the dorsal aspect of surviving larvae. The images were captured using a Hayear Mod. HY-2307 digital camera microscope and S-EYE 1.4-2.474 software. We calibrated and took measurements from the images using Image J (version vi.52k, 2019, National Institutes of Health, $\mathrm{MD})$. The body length (Bl) $(\mu \mathrm{m})$, head-width ( $\mathrm{Hd})$ (midbrain) measurement $(\mu \mathrm{m})$, ocular distance (OD) using the distance between the inner edge of the two eyes $(\mu \mathrm{m})$ (similar to the inner intercanthal distance in humans) and eye diameter (ED) $(\mu \mathrm{m})$ were evaluated (CADENA et al., 2020).

\subsection{Data management and statistical analysis}

Acute fish and embryotoxicity data were collated in EXCEL spreadsheets. The statistical analysis for the assays with embryos was showed in authentic triplicate (OECD 236, 2013). In the statistical analyses, all data are given by mean \pm SD. Morphometry and heartbeats were investigated 
by one-way ANOVA. When the difference was significant, means were associated with the Tukey test with $\mathrm{p}<0.05$. Statistical analyses were performed using the Origin Pro Academic 2015 (Origin Lab. Northampton, MA USA).

\section{Results}

\section{I. Gabapentin}

The acute toxicity test revealed that the mortality of animals increased among the time (24 to $96 \mathrm{hpf}$ ). All deaths occurred due to the presence of coagulation (Table I, Figure I). The sublethal parameters (Table 2) revealed that there was a significant $(p<0.05)$ variation in the number of heartbeats, but not dose-dependent manner at 24-72 hpf. However, there was an increase $(p<0.05)$ in the heartbeats at $96 \mathrm{hpf}$. It was possible to observe the increase in pigmentation in embryos and larvae. The pericardial edema was observed in all groups in embryos and larvae in a dose-dependent manner. No changes were observed in the formation of somites, development of eyes, spontaneous movement, and heartbeat/blood circulation in the animals exposed to GAB.

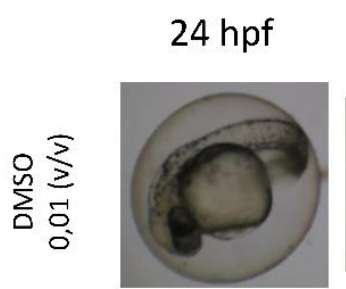

$48 \mathrm{hpf}$

$72 \mathrm{hpf}$

$96 \mathrm{hpf}$
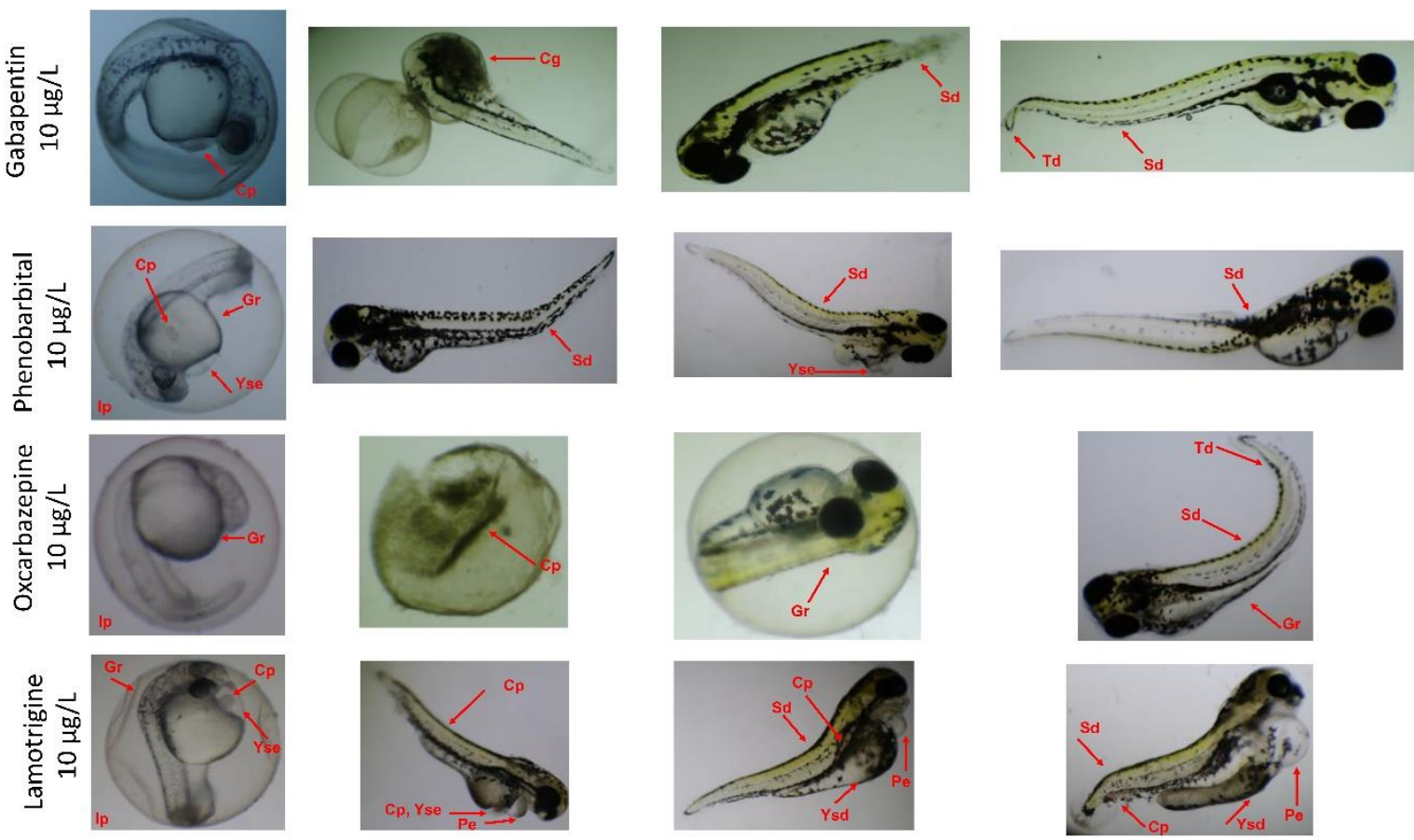

Figure I 
The endpoints of teratogenicity revealed that there was malformation of the head visualized in all groups at $96 \mathrm{hpf}$ (Table 3). The tail deformation was present at 48 and $72 \mathrm{hpf}$ only in the animals exposed to rooo $\mu \mathrm{g} / \mathrm{L}$ of GAB. Besides, in the $96 \mathrm{hpf}$, this teratogenicity was present in all groups. The spine deformation was present in all groups at 48, 72, and $96 \mathrm{hpf}$. However, in the 96 hpf, the effect is more severe. The yolk sac edema and inflated swim bladder were absent in all groups. The growth retardation was present in all groups in the $24-72 \mathrm{hpf}$, being absent in all groups in the $96 \mathrm{hpf}$. The coagulation points were present in all groups at $24-96 \mathrm{hpf}$. No changes were observed in the malformation of the heart. From the morphometric parameters, it was a significant $(\mathrm{p}<0.05)$ variation in the body length, head-width, ocular distance, the distance between eyes, and eye diameter in all groups (Table 4 ).

\subsection{Phenobarbital}

The acute toxicity test revealed that the mortality of animals increased among the time 24 to $96 \mathrm{hpf}$ ). All deaths occurred due to the presence of coagulation (Table I). The sublethal parameters (Table 2) revealed that there was a significant $(\mathrm{p}<0.05)$ variation in the number of heartbeats, but not dose-dependent manner at 24-96 hpf. It was possible to observe an increase in the pigmentation

of animals at $24-72 \mathrm{hpf}$. However, there was an absence of the increased pigmentation in all groups at $96 \mathrm{hpf}$. The increase in the presence of pericardial edema was observed in all groups in the embryo stage ( 24 and $48 \mathrm{hpf}$ ). However, in the larvae stage, there was a reduction at 72 to $96 \mathrm{hpf}$. No changes were observed in the formation of somites, development of eyes, spontaneous movement, and heartbeat/blood circulation in the animals exposed to PB. The endpoints of teratogenicity revealed that there was no tail deformation (Table 3). The spine deformation was present at $48 \mathrm{hpf}$; however, in the larvae stage, there an increase of severity at 100 to $1000 \mu \mathrm{g} / \mathrm{L}$ in 72 and $96 \mathrm{hpf}$. The yolk sac edema and inflated swim bladder were present in all groups at 24,48 , and $72 \mathrm{hpf}$, but it was not observed in all groups at $96 \mathrm{hpf}$. The growth retardation was only observed in the embryo stage at 24 and $48 \mathrm{hpf}$. The coagulation points were present in all groups at 24 to $96 \mathrm{hpf}$. No changes were observed in the malformation of the heart. Embryos are protected by the chorion and larvae are not. Therefore, larvae are most affected. From the morphometric parameters, it was a significant ( $\mathrm{p}<$ 0.05) variation in the body length, head-width, ocular distance, the distance between eyes, and eye diameter in all groups (Table 4 ) as same the GAB. 


\subsection{Oxcarbazepine}

The acute toxicity test revealed that the mortality of animals increased among the time (24 to $96 \mathrm{hpf}$ ). The presence of coagulation explains it in the 1o and $100 \mu \mathrm{g} / \mathrm{L}$, but in the $1000 \mu \mathrm{g} / \mathrm{L}$ no heartbeat was also observed at $48 \mathrm{hpf}$ (Table I). The sublethal parameters (Table 2) revealed that there was a significant decrease $(p<0.05)$ in the number of heartbeats at $24-72 \mathrm{hpf}$, but this decrease was only observed in the rooo $\mu \mathrm{g} / \mathrm{L}$ at $96 \mathrm{hpf}$. No changes were observed in the formation of somites, development of eyes, spontaneous movement, and heartbeat/blood circulation in the animals exposed to OX. The endpoints of teratogenicity revealed that there was no tail deformation in all groups exposed at 24 and $48 \mathrm{hpf}$ (Table 3). However, they were present in the animals exposed to the concentrations of 100 and $1000 \mu \mathrm{g} / \mathrm{L}$ in the 72 and $96 \mathrm{hpf}$. The spine deformation was present in the animals exposed to Ioo and Iooo $\mu \mathrm{g} / \mathrm{L}$ of OX at 48 and $72 \mathrm{hpf}$. Also, all the groups exhibited the endpoint at $96 \mathrm{hpf}$. The yolk sac edema was observed in the high concentrations in the animals after $48 \mathrm{hpf}$. The inflated swim bladder, growth retardation, and coagulations points were present in all groups. Malformation of the head and malformation of the heart were not observed. From the morphometric parameters, it was a significant $(\mathrm{p}<0.05)$ variation in the body length, head-width, ocular distance, the distance between eyes, and eye diameter in all groups (Table 4 ) as same the $\mathrm{GAB}$ and $\mathrm{PB}$.

\subsection{Lamotrigine}

The acute toxicity test revealed that the mortality of animals increased among the time (24 to $96 \mathrm{hpf}$ ). No heartbeat explains it at $48 \mathrm{hpf}$ and the presence of coagulation at $96 \mathrm{hpf}$ (Table I). The sublethal parameters (Table 2$)$ revealed that there was a significant $(\mathrm{p}<0.05)$ variation in the number of heartbeats, but not dose-dependent manner at 24-96 hpf. The increased pigmentation was only observed at $24 \mathrm{hpf}$ in the embryo stage but is more severe in the larvae stage at $96 \mathrm{hpf}$. The pericardial edema was only observed at $24 \mathrm{hpf}$. The formation of somites, development of eyes, spontaneous movement, and heartbeat/blood circulation were not observed in the animals exposed LTG. The only teratogenic effect observed is points of coagulation in the embryo stage (Table 3). However, in the larvae stage, it was observed the tail deformation and spine deformation. The animals did not present growth retardation, malformation of the head, and malformation of the heart. From the morphometric parameters, it was a significant $(\mathrm{p}<0.05)$ variation in the body length, head-width, ocular distance, the distance between eyes, and eye diameter in all groups (Table 4) as same the other antiepileptics. 


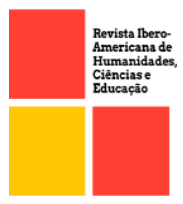

Revista Ibero- Americana de Humanidades, Ciências e Educação- REASE

OPEN ${ }_{\text {ACCESS }}$

Table r: Lethal endpoints observed during experiments on zebrafish embryos after exposure to individual compounds in different concentrations. No effects were observed in the animals of the control (DMSO < 0.1\%) group. According to Lammer et al. (2009) and OECD 236 (2013).

\begin{tabular}{|c|c|c|c|c|c|c|c|c|c|c|c|c|c|}
\hline & & & & & & & & & & & & & \\
\hline Time & Lethal Endpoints & $\begin{array}{c}\mathrm{GAB} \\
(\text { ro } \mu \mathrm{g} / \mathrm{L})\end{array}$ & $\begin{array}{c}\mathrm{GAB} \\
(\text { roo } \mu \mathrm{g} / \mathrm{L})\end{array}$ & $\begin{array}{c}\mathrm{GAB} \\
\text { (1ооо } \mu \mathrm{g} / \mathrm{L})\end{array}$ & $\begin{array}{c}\mathrm{PB} \\
\text { (1о } \mu \mathrm{g} / \mathrm{L} \text { ) }\end{array}$ & $\begin{array}{c}\mathrm{PB} \\
\text { (100 } \mu \mathrm{g} / \mathrm{L})\end{array}$ & $\begin{array}{c}\mathrm{PB} \\
(\text { (rooo } \mu \mathrm{g} / \mathrm{L})\end{array}$ & $\begin{array}{c}\mathrm{OX} \\
\text { (1о } \mu \mathrm{g} / \mathrm{L} \text { ) }\end{array}$ & $\begin{array}{c}\mathrm{OX} \\
(\text { (10о } \mu \mathrm{g} / \mathrm{L})\end{array}$ & $\begin{array}{c}\mathrm{OX} \\
(\text { (оооо } \mu \mathrm{g} / \mathrm{L})\end{array}$ & $\begin{array}{c}\text { LTG } \\
(\text { (1o } \mu \mathrm{g} / \mathrm{L})\end{array}$ & $\begin{array}{c}\text { LTG } \\
(1000 \mu / \mathrm{L})\end{array}$ & $\begin{array}{c}\mathrm{LTG} \\
(\mathrm{Looo} \mu \mathrm{g} / \mathrm{L})\end{array}$ \\
\hline \multirow{5}{*}{$24 \mathrm{hpf}$} & Coagulation & + & + & + & + & + & + & + & + & + & & & \\
\hline & Tail not detached & & & & & & & & & & & & \\
\hline & No somite formation & & & & & & & & & & & & \\
\hline & $\begin{array}{l}\text { No heart-beat } \\
\text { Lack of hatching }\end{array}$ & & & & & & & & & & & & \\
\hline & Mortality $(\%)$ & 6.7 & 16.7 & 10.0 & 13.3 & 6.6 & 3.3 & 10.0 & 3.3 & 3.3 & & & \\
\hline \multirow{6}{*}{$48 \mathrm{hpf}$} & $\begin{array}{c}\text { Coagulation } \\
\end{array}$ & + & ++ & + & + & + & + & + & + & + & & & \\
\hline & Tail not detached & & & & & & & & & & & & \\
\hline & No somite formation & & & & & & & & & & & & \\
\hline & No heart-beat & & & & & + & & & & + & & & \\
\hline & Lack of hatching & & & & & & & & & & & & \\
\hline & Mortality (\%) & $\mathrm{ro}, \mathrm{o}$ & 26,6 & 16,7 & I3.3 & 6,6 & 13,3 & 10.0 & 3.3 & 10.0 & & & \\
\hline \multirow{6}{*}{$72 \mathrm{hpf}$} & Coagulation & + & ++ & ++ & + & + & + & + & + & + & & & \\
\hline & Tail not detached & & & & & & & & & & & & \\
\hline & No somite formation & & & & & & & & & & & & \\
\hline & No heart-beat & & & & & & & & & & + & & \\
\hline & Lack of hatching & & & & & & & & & & & & \\
\hline & Mortality $(\%)$ & 16.7 & 26.6 & 30.0 & 13.3 & 6,6 & 16,6 & 10.0 & 3.3 & 13.3 & 3.3 & & \\
\hline \multirow{3}{*}{$96 \mathrm{hpf}$} & $\begin{array}{c}\text { Coagulation } \\
\text { Tail not detached }\end{array}$ & + & ++ & ++ & + & ++ & + & + & + & + & + & & + \\
\hline & $\begin{array}{l}\text { No somite formation } \\
\text { No heart-beat }\end{array}$ & & & & & & & & & & & & \\
\hline & Lack of hatching & & & & & & & & & & & & \\
\hline
\end{tabular}

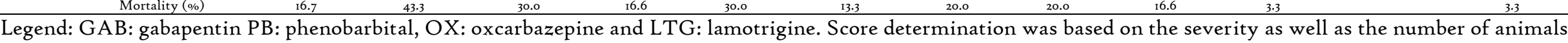
out of the total in which changes were observed with plus $(+)=$ effects until $25 \%$ of animals (mild); $(++)=$ effects in more $25 \%$ until $50 \%$ of animals $($ moderate $) ;(+++)=$ more $50 \%$ until $75 \%$ of animals (severe); $(++++)$ more $75 \%$ of animals (very severe). 
Table 2: Sublethal developmental endpoints observed during experiments on zebrafish embryos after exposure to individual compounds in different concentrations. No effects were observed in the animals of control (DMSO < 0.1\%) group. According to Lammer et al. (2009) and OECD 236 (2013).

Legend: Nh - number of heartbeats. GAB: gabapentin PB: phenobarbital, OX: oxcarbazepine and LTG: lamotrigine. Score determination was based on the severity as

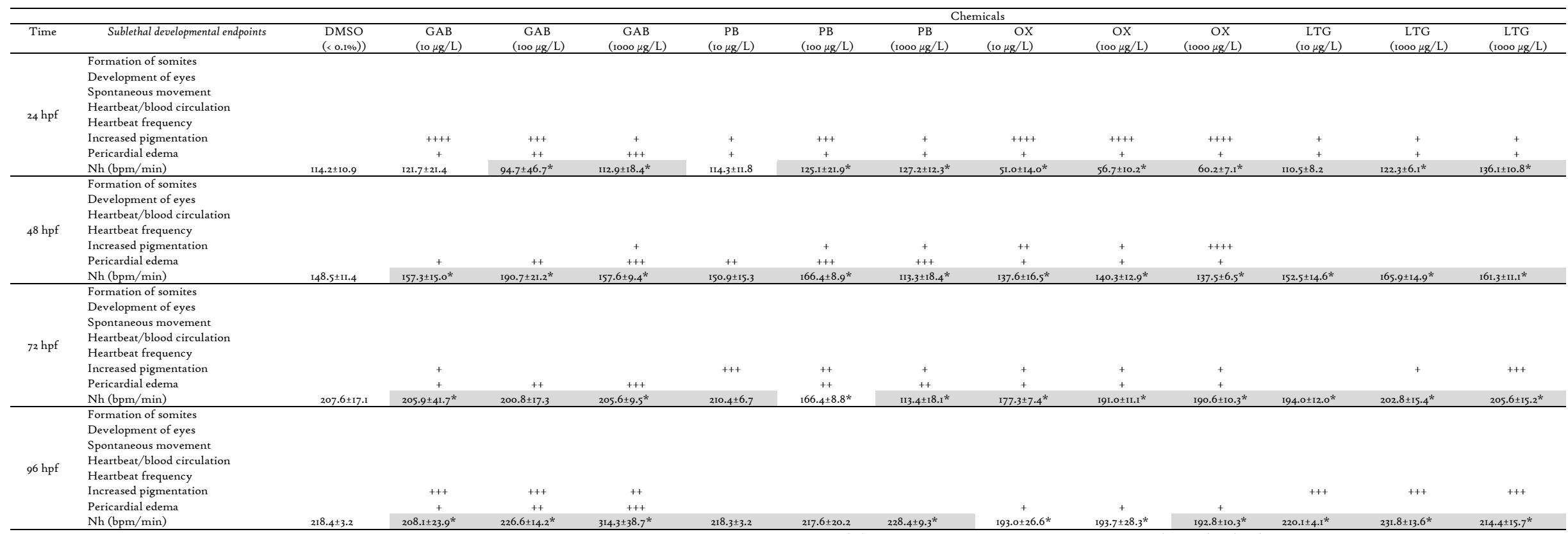
well as the number of animals out of the total in which changes were observed with plus (+) = effects until $25 \%$ of animals (mild); (++) $=$ effects in more $25 \%$ until $50 \%$ of animals (moderate); $(+++)=$ more $50 \%$ until $75 \%$ of animals (severe); (++++) more $75 \%$ of animals (very severe). 4966 Significative difference (p $<$ o.o5) to control (DMSO) group according to Tukey Test. 


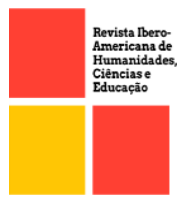

Revista Ibero- Americana de Humanidades, Ciências e Educação- REASE

oPEN ${ }_{\text {ACCESS }}$

Table 3: Endpoints of teratogenicity observed during experiments on zebrafish embryos after exposure to individual compounds in different concentrations. No effects were observed in the animals of the control (DMSO < 0.1\%) group. According to Lammer 2009 and OECDE (2013).

\begin{tabular}{|c|c|c|c|c|c|c|c|c|c|c|c|c|c|}
\hline Time & Endpoints of teratogenicity & $\begin{array}{c}\mathrm{GAB} \\
(\mathrm{or} \mu \mathrm{g} / \mathrm{L}) \\
\end{array}$ & $\begin{array}{c}\mathrm{GAB} \\
(\mathrm{G} 10 \mathrm{\mu g} / \mathrm{L}) \\
\end{array}$ & $\begin{aligned} \mathrm{GAB} \\
(\mathrm{rooo} \mu \mathrm{g} / \mathrm{L}) \\
\end{aligned}$ & $\begin{array}{c}\mathrm{PB} \\
(\mathrm{PB} \mu \mathrm{L} / \mathrm{L}) \\
\end{array}$ & $\begin{array}{c}\mathrm{PB} \\
\text { (10о } \mu \mathrm{g} / \mathrm{L}) \\
\end{array}$ & $\begin{array}{c}\text { Chemicals } \\
\mathrm{PB} \\
(\mathrm{ro} / \mathrm{\mu g} / \mathrm{L})\end{array}$ & $\begin{array}{c}\mathrm{OX} \\
(\mathrm{O} \mu \mathrm{g} / \mathrm{L}) \\
\end{array}$ & $\begin{array}{c}\mathrm{OX} \\
(100 \mu \mathrm{L} / \mathrm{L}) \\
\end{array}$ & $\begin{array}{c}\mathrm{OX} \\
(1000 \mathrm{\mu g} / \mathrm{L}) \\
\end{array}$ & $\begin{array}{c}\mathrm{LTG} \\
(\mathrm{ro} \mu \mathrm{g} / \mathrm{L}) \\
\end{array}$ & $\begin{array}{c}\mathrm{LTG} \\
(\mathrm{rooo} \mu \mathrm{\mu g} / \mathrm{L})\end{array}$ & $\begin{array}{c}\mathrm{LTG} \\
(\mathrm{rooo} \mu \mathrm{\mu g} / \mathrm{L})\end{array}$ \\
\hline \multirow{6}{*}{$24 \mathrm{hpf}$} & $\begin{array}{l}\text { Malformation of the head } \\
\text { Malformation of heart }\end{array}$ & & & & & & & & & & & & \\
\hline & $\begin{array}{l}\text { Tail deformation } \\
\text { Spine deformation }\end{array}$ & & & & & & & & & & & & \\
\hline & $\begin{array}{l}\text { Spinine deformation } \\
\text { Yolk sac edema }\end{array}$ & & & & ++ & & & & & & & & \\
\hline & Inflated swim bladder & & & & it & & & + & + & + & & & \\
\hline & $\begin{array}{l}\text { Growth retardation } \\
\text { Coasulation points }\end{array}$ & +++ & + & + & + & + & & ${ }_{n+++}$ & t+t+ & t+t+ & & & \\
\hline & $\begin{array}{l}\text { Coagulation points } \\
\text { Malformation of the hat }\end{array}$ & & & & & & & & & + & ++ & ++ & ++ \\
\hline \multirow{6}{*}{$48 \mathrm{hpf}$} & $\begin{array}{l}\text { Malformation of the head } \\
\text { Malformation of heart }\end{array}$ & & & & & & & & & & & & \\
\hline & Tail deformation & & & + & & & & & & & & & \\
\hline & $\begin{array}{l}\text { Spine deformation } \\
\text { Yolk sacedema }\end{array}$ & + & + & + & & + & & & + & + & & & \\
\hline & $\begin{array}{l}\text { Yolk sacedema } \\
\text { Inflated swim bladder }\end{array}$ & & & & + & + & + & + & + & + & & & \\
\hline & Growth retardation & & +++ & & + & + & + & ++++ & ++++ & t+t+ & & & \\
\hline & Coagulation points & +t & +t+ & ++ & ++ & +++ & +++ & ++ & + & + & ++ & ++ & + \\
\hline \multirow{6}{*}{$72 \mathrm{hpf}$} & $\begin{array}{l}\text { Malformation of the head } \\
\text { Malformation of heart }\end{array}$ & & & & & & & & & & & & \\
\hline & $\begin{array}{l}\text { Malformation of heart } \\
\text { Tail deformation }\end{array}$ & & & + & & & & & + & + & + & +++ & + \\
\hline & Spine deformation & + & + & + & & + & t+ & & + & + & + & & + \\
\hline & $\begin{array}{l}\text { Yolk sac edema } \\
\text {. }\end{array}$ & & & & + & + & ${ }^{++}$ & & & + & & & \\
\hline & Inflated swim bladder & & & & & & & + & + & + & & & \\
\hline & $\begin{array}{l}\text { Growth retardation } \\
\text { Cogarlation pints. }\end{array}$ & ${ }_{+++}^{++}$ & ${ }_{+++}^{++}$ & +1 & $t$ & + & & ++++ & 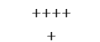 & t+t+ & & & \\
\hline \multirow{6}{*}{$96 \mathrm{hpf}$} & $\begin{array}{l}\text { Malformation of the head } \\
\text { Malformation of heart }\end{array}$ & + & + & + & & & & & & & & & \\
\hline & $\begin{array}{l}\text { Naatormation of neart } \\
\text { Tail deformation }\end{array}$ & ++ & +++ & ${ }^{+++}$ & & & & & + & + & + & & + \\
\hline & Spine deformation & ++ & t+t+ & t+t+ & & + & ++ & + & + & + & + & & + \\
\hline & $\begin{array}{l}\text { Yolk sac edema } \\
\text { Ifllad }\end{array}$ & & & & & & & & + & + & & & \\
\hline & Growth retardation & & & & & & & $t_{+++}^{+}$ & 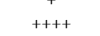 & $+a++$ & & & \\
\hline & Coagulation points & ${ }_{++}^{+}$ & ${ }_{++}^{++}$ & ${ }_{++}^{+}$ & ++ & + & + & ${ }_{++}^{+}$ & + & ++ & & & \\
\hline
\end{tabular}

Legend: GAB: gabapentin PB: phenobarbital, OX: oxcarbazepine and LTG: lamotrigine. Score determination was based on the severity as well as the number of animals

out of the total in which changes were observed with plus $(+)=$ effects until $25 \%$ of animals $($ mild $) ;(++)=$ effects in more $25 \%$ until $50 \%$ of animals $($ moderate); $(+++)=$ more $50 \%$ until $75 \%$ of animals (severe); $(++++)$ more $75 \%$ of animals (very severe). 
Table 4: Morphometry of Danio rerio larvae with $96 \mathrm{hpf}$ exposed to antiepileptics.

\begin{tabular}{|c|c|c|c|c|c|c|c|c|c|c|c|c|c|}
\hline \multirow[b]{2}{*}{$\begin{array}{l}\text { Morphometric } \\
\text { Analysis }\end{array}$} & \multirow[b]{2}{*}{$\underset{0.1 \%)}{\operatorname{DMSO}(<}$} & \multicolumn{12}{|c|}{ Chemicals } \\
\hline & & $\begin{array}{c}\mathrm{GAB} \\
(\mathrm{ro} \mu \mathrm{g} / \mathrm{L})\end{array}$ & $\begin{array}{c}\text { GAB } \\
(\text { เоo } \mu \mathrm{g} / \mathrm{L})\end{array}$ & $\begin{array}{c}\mathrm{GAB} \\
(\text { (оооо } \mu \mathrm{g} / \mathrm{L})\end{array}$ & $\begin{array}{c}\mathrm{PB} \\
(\mathrm{ro} \mu \mathrm{g} / \mathrm{L})\end{array}$ & $\begin{array}{c}\mathrm{PB} \\
(\mathrm{1oo} \mu \mathrm{g} / \mathrm{L})\end{array}$ & $\begin{array}{c}\text { PB } \\
\text { (гооо } \mu \mathrm{g} / \mathrm{L})\end{array}$ & $\begin{array}{c}\mathrm{OX} \\
(\text { (о } \mu \mathrm{g} / \mathrm{L})\end{array}$ & $\begin{array}{c}\mathrm{OX} \\
(\text { (оо } \mu \mathrm{g} / \mathrm{L})\end{array}$ & $\begin{array}{c}\mathrm{OX} \\
(\text { (1ооо } \mu \mathrm{g} / \mathrm{L})\end{array}$ & $\begin{array}{c}\text { LTG } \\
(\text { (о } \mu \mathrm{g} / \mathrm{L})\end{array}$ & $\begin{array}{c}\mathrm{LTG} \\
(\text { 1оo } \mu \mathrm{g} / \mathrm{L})\end{array}$ & $\begin{array}{c}\text { LTG } \\
(\text { оооо } \mu \mathrm{g} / \mathrm{L})\end{array}$ \\
\hline $\mathrm{Bl}$ & $3.918 .5 \pm 44.9$ & $3549.5 \pm 161.6 *$ & $3685.7 \pm 61.8^{*}$ & $3575.5 \pm 95.2^{*}$ & $3355.8 \pm 106.9^{*}$ & $3357.1 \pm 94.9^{*}$ & $3388.0 \pm 25.6^{*}$ & $3374 \cdot 1 \pm 54,8^{*}$ & $3923.3 \pm 59.9^{*}$ & $3426.8 \pm 95.2^{*}$ & $3690.4 \pm 57.5^{*}$ & $3883.8 \pm 114.7^{*}$ & $3872.1 \pm 43.5^{*}$ \\
\hline $\mathrm{Hd}$ & $515.7 \pm 4,0$ & $477.1 \pm \mathrm{I} 3.8^{*}$ & $499.7 \pm 9.6^{*}$ & $492.3 \pm 16.8^{*}$ & $477.1 \pm \mathrm{I} 3.8^{*}$ & $499.7 \pm 9.6^{*}$ & $492.3 \pm 16.8^{*}$ & $442.3 \pm 20.8$ & $444.7 \pm 18.7 *$ & $452.1 \pm 8.7^{*}$ & $510.9 \pm 20.1$ & $526.9 \pm 18.9^{*}$ & $526.8 \pm 31.6^{*}$ \\
\hline Od & $128.3 \pm 1.5$ & $109.7 \pm 16.1^{*}$ & $97.1 \pm 12.7^{*}$ & $94.3 \pm 18.9^{*}$ & $77.5 \pm 9.6^{*}$ & $98.9 \pm \mathrm{II} .6^{*}$ & $94.7 \pm \mathrm{I} 8 . \mathrm{I}^{*}$ & $117.4 \pm 14.2^{*}$ & $110.9 \pm 19.2^{*}$ & $106.4 \pm 10.5^{*}$ & $84.3 \pm 19.1^{*}$ & $90.6 \pm 34 . \mathrm{I}^{*}$ & $108.9 \pm 24.9^{*}$ \\
\hline $\mathrm{Ed}$ & $324.1 \pm$ 101. 6 & $288.1 \pm 35.7^{*}$ & $330.7 \pm 20.1^{*}$ & $31 \mathrm{II} .4 \pm 16.2^{*}$ & $337.1 \pm 64.8$ & $306.6 \pm 13.6^{*}$ & $308.2 \pm 9.6^{*}$ & $304.5 \pm 37 . \mathrm{I}^{*}$ & $298.4 \pm 24 \cdot 4^{*}$ & $311.2 \pm 23.2^{*}$ & $334.7 \pm 15.1^{*}$ & $330.5 \pm 20.4^{*}$ & $337.2 \pm 12.4^{*}$ \\
\hline
\end{tabular}

Legend: Bl: Body Length; Hd: Head-Width; Od: Ocular distance, distance between eyes; Ed: Eye diameter; LA: lamotrigine, GA: gabapentin PH: phenobarbital and OX: oxcarbazepine. * Significant statistical difference in relation to the control $(\mathrm{p}<0.05)$ by the Tukey test. 


\section{Discussion}

The attitudes of society towards the disposal of indiscriminate drugs can cause serious damage to the environment and the population itself. The lack of understanding of the lethal, sublethal, teratogenic, and morphometric effects caused by the disposal of Gabapentin (GAB), Phenobarbital (PB), Oxcarbazepine (OX), and Lamotrigine (LTG) also makes prevention difficult. In this work, it was analyzed the lethal, sublethal, teratogenic, and morphometric effects caused by the disposal of Gabapentin (GAB), Phenobarbital (PB), Oxcarbazepine (OX), and Lamotrigine (LTG) on the development of zebrafish.

The lethal endpoints analyzed were coagulation $(\mathrm{Cg})$, tail not detached (Tnd), no somite formation (Nsf), no heartbeat (Nhb), lack of hatching (Lh), and mortality (Mo) (\%) (Lammer et al., 2009). The most recent works that drug the number of heartbeats at $48 \mathrm{hpf}$ is frequently used as an indicator to assess adverse effects of pollutants are important to highlight being (Li et al., 2018; Fraysse, Mons and Garric, 2006). The heart is the first organ formed in the zebrafish. The heart can be visualized quickly due to the transparent development of this animal. Its beat is regularized between 36 and $48 \mathrm{hpf}$ and this parameter is directly linked to the temperature ( $\mathrm{Li}$ et al., 2018). Carbamazepine and valproic acid significantly decrease the heartbeat of zebrafish embryos according to the dose at which the embryos are exposed (Pruvot et al., 2012). However, the use of gabapentin increased the frequency of zebrafish, as well as mammals suggesting GABA activated the circulatory system of zebrafish and this might be caused by the mechanism of GAB to the nervous system of zebrafish. Furthermore, GABA toxicity tests show children who have become hyperactive and have aggressive behavior (Wolf et al., 1996). This strongly indicates GA has adverse effects on the development of zebrafish.

Sublethal developmental endpoints analyzed were the formation of somites (Fs), development of eyes (De), heartbeat/blood circulation ( $\mathrm{Hbc}$ ), heartbeat frequency (Hf), increased pigmentation (Ip), pericardial edema ( $\mathrm{Pe})$, Number of heartbeats $(\mathrm{Nh})(\mathrm{bpm} / \mathrm{min})$ (Lammer et al., 2009). Pericardial edema is the most popular indicator in zebrafish toxicity tests (Li et al., 2018; Fraysse, Mons, and Garric, 2006).

Endpoints of teratogenicity were malformation of the head (Mhd), malformation of the heart (Mh), tail deformation ( $\mathrm{Td}$ ), spine deformation (Sd), yolk sac edema (Yse), inflated swim bladder (Isb), growth retardation (Gr) and coagulation points (Cp) (Lammer et al., 2009). A reducing tendency was observable on the body length of zebrafish by effect of GA (Li et al., 2018). Carbamazepine induced an increase in body length. However, exposure to 
GAB caused a concentration-dependent decrease in the body length of zebrafish at $72 \mathrm{hpf}(\mathrm{Li}$ et al., 2018). The tail size is also an important indicator to assess the toxicity of chemicals. Tail size decreases due to exposure to pollutants (Fraysse, Mons, and Garric, 2006). Normal hatching was observed, and the morphology was not altered in the animals exposed to $\mathrm{PH}$ and LA in concentrations up to roo $\mu \mathrm{M}$ (Martinez et al., 2018). Among the antiepileptic drugs analyzed LA is the most appropriate candidate since it performs well as an antiepileptic drug at low doses and it does not present teratogenic or neurotoxic effects (Martinez et al., 2018).

Some studies address the development of the zebrafish cardiovascular system in a detailed way ( $\mathrm{Li}$, et al., 2003; Berndt, et al., 2014), correlating as changes to oxidative stress ( $\mathrm{Ni}$, et al., 2020), crest cell neural migration ( $\mathrm{Li}$, et al., 2003; Berndt, et al., 2014), lipid metabolism, receptor-mediated biotransformation (Antkiewicz, Peterson, Heideman, 2006), early differentiation of cardiomyocytes (Roi, et al., 2016), or retinoic acid metabolism (Sarmah and Marrs, 2013; Wu, et al., 2013).

However, few studies address this (eco) toxicological theme (Manjunatha et al., 2020). In animals with mild edema, they resemble the enlarged pericardium, however, severe cases can be taken as thin-walled cavities around the heart. It can develop outside the yolk sac or concentrate in cavities inside the egg. Edema can appear throughout the body, found among the vacancies in the present study, being classified as nonspecific. The edema observed in the development of zebrafish embryos appears to be reversible if it does not occur in severe form.

\section{Conclusion}

In this work, we studied lethal, sublethal, teratogenic effects, and morphometric alterations on embryos and larvae of zebrafish of the antiepileptic drugs GAB, PB, OX, and LTG. The present study found that the acute toxicity test revealed that the mortality of animals increased among the time in animals exposed to GAB, PB, OX, and LTG. We demonstrated that the sublethal parameters revealed that there was significant variation in a number of heartbeats concentrations in animals exposed to GAB, PB, OX, and LTG.

It was possible to observe variation in pigmentation and the presence of pericardial edema. The endpoints of teratogenicity revealed that there was malformation of the head visualized only in the animals exposed to GAB.

It was possible to observe the presence of tail deformation, spine deformation, yolk sac edema and inflated swim bladder in the animals exposed to GAB, PB, OX, and LTG. From the morphometric analysis, it was observed a decrease in body length, head-width, 
ocular distance, the distance between eyes, and eye diameter in all groups. Based on results, the OX is the more toxic compound studied and LTG is the less toxic.

These results draw our attention to possible adverse effects of $G A B, P B, O X$, and LTG in the environment and help scientists as well as regulators to prepare measures to reduce the toxic effects of these compounds.

\section{Acknowledgments}

The authors would like to thank the Universidade Federal de Pernambuco, Coordenação de Aperfeiçoamento de Pessoal de Nível Superior - CAPES to the scholarship to Islane C. Martins, Conselho Nacional de Desenvolvimento Científico e Tecnológico CNPq for the productivity grant to Pabyton G. Cadena (310401/2017-8).

\section{References}

Altenhofen, S., Nabinger, D.D., Wiprich, M.T., Pereira, T.C.B. Bogo, M.R., Bonan, C.D., 2017. Tebuconazole alters morphological, behavioral and neurochemical parameters in larvae and adult zebra fish (Danio rerio). Chemosphere. 180, 483490.

Antkiewicz DS, Peterson RE, Heideman W (2006) Blocking expression of AHR2 and ARNTI in zebrafish larvae protects against cardiac toxicity of $2,3,7,8-$ tetrachlorodibenzo-p-dioxin. Toxicol Sci 94:175-182. https://doi.org/Io.I093/toxsci/kflo93

Bahlmann, A., Brack, W., Schneider, R.J., Krauss, M., 2014. Carbamazepine and its metabolites in wastewater: analytical pitfalls and occurrence in Germany and Portugal. WR Water Res. 57, I04-II4.

Berndt C, Poschmann G, Sthler K et al (2014) Zebrafish heart development is regulated via glutaredoxin 2 dependent migration and survival of neural crest cells. Redox Biol 2:673-678. https://doi.org/10.1016/j.redox.2014.04.012

Bhakta, J., Bainbridge, J., Borgelt, L., 2015. Teratogenic medications and concurrent contraceptive use in women of childbearing ability with epilepsy. Epilepsy Behav, 52, 212-217.

Chefetz, B., Marom, R., Salton, O., Oliferovsky, M., Mordehay, V., Ben-Ari, J., Hadar, Y., 2019. Transformation of lamotrigine by white-rot fungus Pleurotus ostreatus, 546-533.

Cho SJ, Park E, Baker A, Reid AY. Age Bias in Zebrafish Models of Epilepsy: What Can We Learn From Old Fish? Front Cell Dev Biol. 2020;8(September):I-8.

Cunliffe, V.T., Baines, R.A., Giachello, C.N.G., Wei-Hsiang, L., Morgan, A., Reuber, M., Russell, C., Walker, M.C., Williams, R.S.B., 2015. Epilepsy research methods update: Understanding the causes of epileptic seizures and identifying new treatments using non-mammalian model organisms. Seizure $24,44-5$ I. 
Deo, R.P., 2014. Pharmaceuticals in the surface water of the usa: review Curr. Environ. Health Rep., 2014, I, I13-122.

Dickins, M., Chen, C., 2002. Lamotrigine: Chemistry, biotransformation, and pharmacokinetics. In: Levy RH, Mattson RH, Meldrum BS, Perucca E, editors. Antiepileptic Drugs. 5th ed. Philadelphia: Lippincott Williams \& Wilkins, p. 370-9.

Doll, T.E., Frimmel, F.H., 2005. Removal of selected persistent organic pollutants by heterogeneous photocatalysis in water. Catal. Today, I01, 195-202.

FDA. 2orr. Neurotin (Gabapentin).

Fraysse, B., Mons, R., Garric, J., 2006. Development of a zebrafish 4-day embryolarval bioassay to assess toxicity of chemicals. Ecotoxicol Environ Saf 63, 253-267.

Kim H., Faught E., Thurman DJ., Fishman J., Kalilani L., 2019. Antiepileptic Drug Treatment Patterns in Women of Childbearing Age With Epilepsy, I, I-8.

Lammer, E., CARR, G.J., Wendler, K., Rawlings, J.M., Belanger, S.E. and Braunbeck, T. Is the fish embryo toxicity test (FET) with the zebrafish (Danio rerio) a potential alternative for the fish acute toxicity test? Comp. Biochem. Physiol. Part C Toxicol. Pharmacol., 2009, 149, 196-209.

Le, M.T., Fongb, S., Limb, K.L., Gunadharmac, S., Sejahterad, D.P., Visudtibhanf, A., Chang, D., Vorachith, S., Chani, S., Ohnmarj, Chuak, A.E., Cabral-Limk, L., Yassinl, N., Len, V., Tanb, C., 2019. Underutilization of epilepsy surgery in ASEAN countries. Seizure: European Journal of Epilepsy, 69, 51-56.

Li YX, Zdanowicz M, Young L et al (2003) Cardiac neural crest in zebrafish embryos contributes to myocardial cell lineage and early heart function. Dev Dyn 226:540-550. https://doi.org/10.1002/dvdy.10264

Li, X., Zhou, S., Qian, Y., Xu, Z., Yu, Y., He, Y., Zhang, Y., 2018. The assessment of the ecotoxicological effect of gabapentin on early development of zebrafish and its antioxidant system. RSC Advances, 8, 22777-84.

Lee Y, Seo HW, Lee KJ, Jang JW, Kim S. A microfluidic system for stable and continuous eeg monitoring from multiple larval zebrafish. Sensors (Switzerland). 2020;20(20):I-15.

Manjunatha B, Han L, Kundapur RR et al (2020) Herbul black henna (hair dye) causes cardiovascular defects in zebrafish (Danio rerio) embryo model. Environ Sci Pollut Res 27:14150-I4159. https://doi.org/I0.1007/sir356-020-07762-z

Martinez, C., Canle, M., Fernandez, M.I., Santaballa, J.A., Faria, J., 2orr. Kinetics and mechanism of aqueous degradation of carbamazepine by heterogeneous photocatalysis using nanocrystalline $\mathrm{TiO}_{2}, \mathrm{ZnO}$ and multi-walled carbon nanotubes-anatase composites. Appl. Catal. B-Environ., 102, 563-571.

Morasch, B., Bonvin, F., Reiser, H., Grandjean, D., Alencastro, L.F., Perazzolo, C., Ch 'ever, N., Kohn, T., 2010. Occurrence and fate of micropollutants in the Vidy Bay of Lake Geneva, Switzerland. Part I: Priority list for environmental risk assessment of pharmaceuticals. Environ. Toxicol. Chem., 2010, 29, 1658I668.

Nakayama, S., Johnstone, R.A., Manica, A., 2012. Temperament and hunger interact to determine the emergence of leaders in pairs of foraging fish. PLoS One, 7 , 437-47. 
$\mathrm{Ni}$ J, Wang $\mathrm{H}$, Wei $\mathrm{X}$ et al (2020) Isoniazid causes heart looping disorder in zebrafish embryos by the induction of oxidative stress. BMC Pharmacol Toxicol. https://doi.org/Io.I186/s40360-020-0399-2

OECD (2013), Education at a Glance 2013: OECD Indicators, OECD Publishing. 624 http://dx.doi.org/10.1787/eag-2013-en

Pacifici, G.M., 2014. Clinical pharmacology of analgesics in infants and the pharmacologic management of pain in neonates. MedicalExpress (São Paulo, Online), I, ro5-II5.

Patel, S.I., Pennell, P.B., 2or6. Management of epilepsy during pregnancy: an update. Ther Adv Neurol Disord, 9, I18-I29.

Petrie, B., Barden, R., Kasprzyk-Hordern, B., 2015. A review on emerging contaminants in wastewaters and the environment: current knowledge, understudied areas and recommendations for future monitoring. Water Research, 72, 3-27.

Pohl, J., Ahrens, L., Carlsson, G., Golovko, O., Norrgre, L., Weiss, J., Örn, S., 2019. Embryotoxicity of ozonated diclofenac, carbamazepine, and oxazepam in zebrafish (Danio rerio). Chemosphere, 225, 191-199.

Prasad, G., 2019. A theoretical framework for predicting interplay of food with dissolution, permeability, intestinal metabolism and active transport of drugs: Towards mechanistic biopharmaceutical classification system (mBCS), The FASEB Journal 2019 33:I_supplement, 8I4.2-8I4.2

Pruvot, B., Quiroz, Y., Voncken, A., Jeanray, N., Piot, A., Martial, J.A., Muller, M., 2012. A panel of biological tests reveals developmental effects of pharmaceutical pollutants on late stage zebrafish embryos. Reprod. Toxicol, 34, 568-583.

Roy NM, Ochs J, Zambrzycka E, Anderson A (2016) Glyphosate induces cardiovascular toxicity in Danio rerio. Environ Toxicol Pharmacol 46:292-300. https://doi.org/ro.ror6/j.etap.2or6.o8.oro

Santos, L.H.M.L.M., Araújo, A.N., Fachini, A., Pena, A., Delerue-Matos, C., Montenegro, M.C.B.S.M., 2010. Ecotoxicological aspects related to the presence of pharmaceuticals in the aquatic environment. Journal of Hazardous Materials, $175,45-95$.

Sarmah S, Marrs JA (2013) Complex cardiac defects after ethanol exposure during discrete cardiogenic events in zebrafish: prevention with folic acid. Dev Dyn 242:1184-I201. https://doi.org/10.1002/dvdy.24015

Shi, C., He, Y., Liu, J., Lu, Y., Fan, Y., Liang, Y., Xu, Y., 2019. Ecotoxicological Effect of Single and Combined Exposure of Carbamazepine and Cadmium on Female Danio rerio: A Multibiomarker Study. Appl. Sci., 9, I362; I-II.

Shihmanab, B., Goldsteinab, L., Amielab, N., Benningerab, F., 2019. Antiepileptic drug

treatment during pregnancy and delivery in women with epilepsy-A retrospective single center study, I49, 66-69.

Silva, M. C. G. DA et al. 2019. The complexation of steroid hormones into cyclodextrin alters the toxic effects on the biological parameters of zebrafish (Danio rerio). Chemosphere, v. 214, p. 330-340. 
Takahama, C.H., Turini, C.A., Girotto, E., 2014. Profile of exposure to medication among women of reproductive age attended in a Toxicologial Information Center. Ciênc. saúde coletiva, I9, II9I-II99.

Yang, Y., Qi, S., Wang, D., Wang, K., Zhu, L., Chai, T., Wang, C., 2or6. Toxic effects of thifluzamide on zebrafish (Danio rerio). J. Hazard. Mater. 307, 127136.

Yekti, A. P. A., Hsu, H., Wang, W. 2014. The Effect of Paclobutrazol on the Development of Zebrafish (Danio Rerio) Embryos. Zebrafish. II, I-9.

Yumiko, A., Norio, Y., Tsukasa, U., 2019. Drug-Drug Interactions of P-gp Substrates Unrelated to CYP Metabolism, 20, 124-129.

Wang, Y., Lv, L., Yu, Y., Yang, G., Xu, Z., Wang, Q., Cai, L. (2017). Single and joint toxic effects of five selected pesticides on the early life stages of zebrafish ( Denio rerio ). Chemosphere, i70, 6i-67.

Wolf, S.M., Shinnar, S., Kang, H., Gil, K.B., Moshe, K.B., 1996. Gabapentin toxicity in children manifesting as behavioral changes. Epilepsia, 36, 1203-1205.

Writer, J.H., Ferrer, I., Barber, L.B., Thurman, E.M., 2013. Widespread occurrence of neuro-active pharmaceuticals and metabolites in 24 Minnesota rivers and wastewaters. Sci. Total Environ., I, 519-527.

Wu S, Fisher J, Naciff J et al (2013) Framework for identifying chemicals with structural features associated with the potential to act as developmental or reproductive toxicants. Chem Res Toxicol 26:1840-1861. https://doi.org/Io.102I/tx400226u

$\mathrm{Zhu}$ J. et al, 2012. Human cardiotoxic drugs delivered by soaking and microinjection induce cardiovascular toxicity in zebrafish. J. appl. toxicol. 34: I39-I4.

\section{Captions for figures}

Figure I. The teratogenic effects are: Main teratogenic effects are signaled as Cg: coagulation, Cp: Coagulations points, Gr: Growth retardation, Ip: Increased pigmentation, Pe: pericardial edema, Sd: spine deformation, Td: Tail deformation, Ysd: Yolk sac deformation and Yse: yolk sac edema. 